In memoriam Cees Berg (2 July 1934-31 August 2012)

van Welzen, P. C.; Gadella, T. W. J.; Maas, P. J. M.; Daly, D. C.; Mori, S. A.; Jørgensen, P. M.; Obermüller, F. A.; Kjellberg, F.; Rønsted, Nina; Chantarasuwan, B.; Lut, C. W. J.

Published in:

Blumea

DOI:

$10.3767 / 000651913 \times 662362$

Publication date:

2013

Document version

Publisher's PDF, also known as Version of record

Document license:

CC BY-NC-ND

Citation for published version (APA):

van Welzen, P. C., Gadella, T. W. J., Maas, P. J. M., Daly, D. C., Mori, S. A., Jørgensen, P. M., Obermüller, F. A., Kjellberg, F., Rønsted, N., Chantarasuwan, B., \& Lut, C. W. J. (2013). In memoriam Cees Berg (2 July 193431 August 2012). Blumea, 57(3), 199-206. https://doi.org/10.3767/000651913X662362 


\title{
In memoriam Cees Berg (2 July 1934 - 31 August 2012)
}

\author{
P.C. van Welzen, T.W.J. Gadella, P.J.M. Maas, D.C. Daly, S.A. Mori, P.M. Jørgensen, \\ F.A. Obermüller, F. Kjellberg, N. Rønsted, B. Chantarasuwan, C.W.J. Lut
}

Published on 3 January 2013

Cornelis Christiaan Berg, better known as Cees (or 'Kees' for the non-Dutch), was born on 2 July 1934 in the city of Bandung on Java, then still the Netherlands East Indies. Later, the family moved to Sumatra, close to the city of Medan. During the Second World War, when Japan attacked the Netherlands East Indies, Cees' father was conscripted and, unfortunately, died during the invasion. Cees, his four brothers and their mother were interned in a women's camp near Medan. At the age of 10 Cees was moved to a men's camp. This period must have been very traumatic as Cees, after his release, spoke little for a long time. All brothers and their mother survived the war, but shortly after the liberation their mother died of starvation. The five orphans came to the Netherlands, where they were split between two foster families. Cees, together with his youngest brother, came into a household with two daughters. During

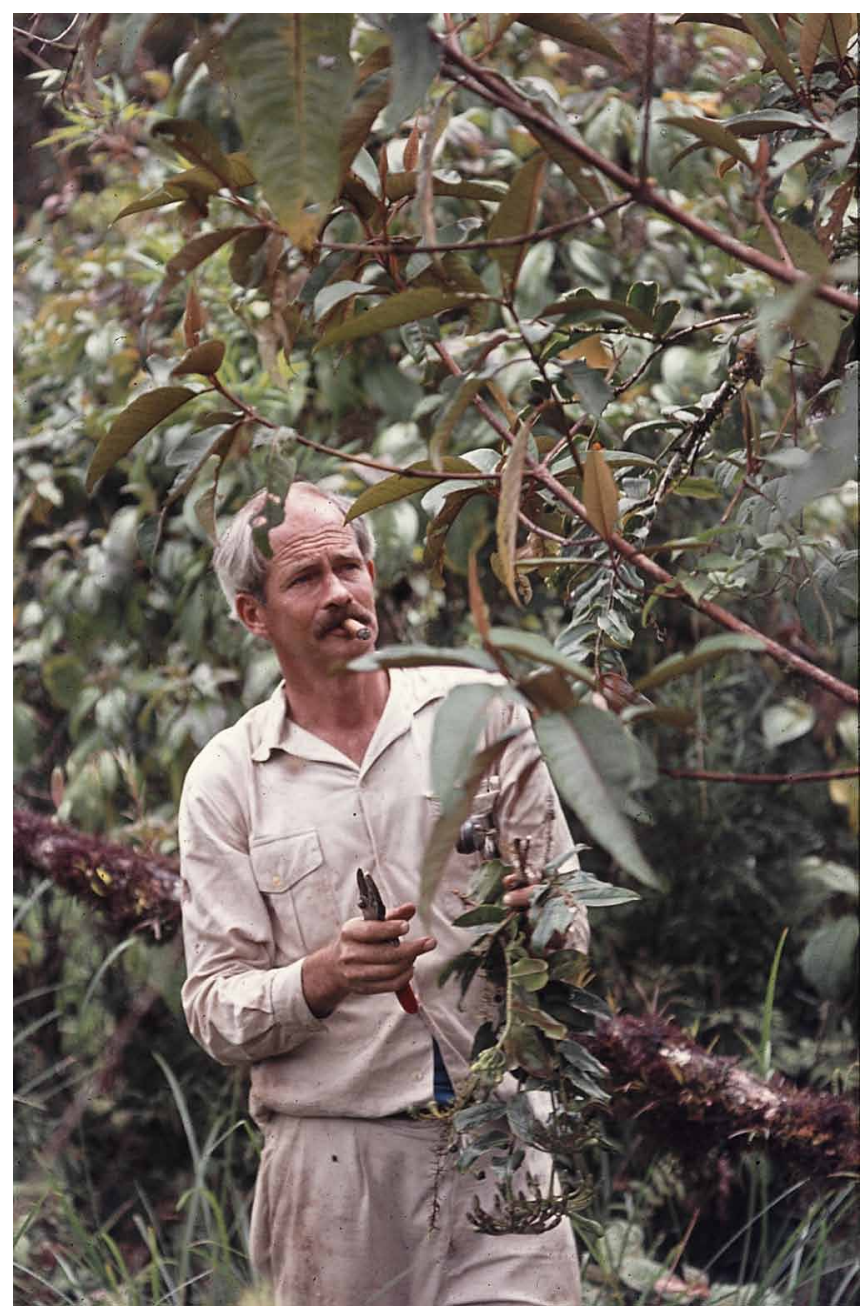

Dr Cigaro collecting a Marcgraviaceae in Ecuador (1977). Photo by Paul Maas. holidays, both families joined so that the brothers were united. Together with the elder daughter, Cees started to explore the forests close to his house. Both studied in Utrecht, Cees majoring in biology and his foster sister studied nursing.

Peter van Welzen

\section{Utrecht, The Netherlands}

As a student, Cees developed an interest in experimental taxonomy, more specifically in the study of polyploidy complexes. He focused his attention on the cytotaxonomic study of two species complexes, Cardamine pratensis s.l. and Myosotis palustris s.l. and used the technique of experimental cultivation for the investigation of genetic differences among populations. He collected many samples of these two species complexes. Later he supervised a cytotaxonomic study of Dorstenia (Moraceae) by one of his students.

Theo Gadella

About 50 years ago Cees Berg and I had a meeting at the Utrecht Herbarium (Netherlands) with its director Prof. J. Lanjouw. After our biology study, we both very much wanted to do a PhD study in plant taxonomy and Lanjouw suggested that we prepare monographs for the Flora Neotropica Project, an international effort that was just about to be started at that time. Lanjouw proposed as subjects for our study the families Moraceae or Zingiberaceae. Cees choose the former, and I the latter. At that time we had no idea that we would work on those plant families for the length of our careers. Cees and I spent several years in completing our respective Flora Neotropica treatments. As was still customary at the time, we conducted our work using herbarium material only, as field work was not necessarily considered to form an essential part of taxonomic studies. We both defended our PhD thesis on the same day, 4 May 1973.

After that period, we worked as staff members at the Utrecht Institute, which included taxonomic studies of (our) respective families and a great deal of teaching and training young students in taxonomy. I particularly remember the course on the Dutch Flora we gave each year, culminating in a week in the southern Dutch province of Limburg, walking through and exploring the beautiful and varied landscapes with many students, and finishing the days in the evenings enjoying excellent Limburgian beer in the bar 'De Kroon' in Gulpen together with Frits Jonker, Ad de Roon, Lubbert Westra, Carolien de Wal, and many other Utrecht staff members.

Cees, in that period, did not feel overly enthusiastic about going into the field. I remember, however, that after I had spent a year in Amazonian Brazil (1971) on several expeditions led by G.T. Prance, I suggested that Cees do the same. He then agreed and went to Brazil, only to become completely 'lost' to

(c) 2013 Nationaal Herbarium Nederland

You are free to share - to copy, distribute and transmit the work, under the following conditions:

Attribution:
Non-commercial: You must attribute the work in the manner specified by the author or licensor (but not in any way that suggests that they endorse you or your use of the work).
You may not use this work for commercial purposes.

No derivative works: You may not alter, transform, or build upon this work.

For any reuse or distribution, you must make clear to others the license terms of this work, which can be found at http://creativecommons.org/licenses/by-nc-nd/3.0/legalcode. Any of the above conditions can be

waived if you get permission from the copyright holder. Nothing in this license impairs or restricts the author's moral rights. 
field work after that experience. Many visits to tropical America followed in order to study Moraceae and Cecropiaceae (a family that Cees newly described) in the field, and those trips were combined with visits to numerous Neotropical herbaria.

In 1977, we went into the field together in Panama, where we were guided by our fantastic guide and dear friend Dr. Bob Dressler. Then we continued our trip to Ecuador, a country with many interesting Moraceae, Cecropiaceae, Urticaceae (and Zingiberaceae). There we made some productive field trips into the Oriente.

But not all went well. One day, Cees driving, we suddenly came to a halt because of a landslide. We were forced to drive through the rubble, but we paid dearly when suddenly a large piece of rock came down on top of our roof. To make things worse, an axle on the left side of our car broke, and we were stuck with little hope of reaching our destination. What to do? Fortunately, one of our team members, Ben ter Welle, arranged for a truck and managed to take the car back to Quito. Of course, Cees and I continued collecting in the meantime! But then we got into a big financial problem, because the insurance did not cover expenses for trips to the Amazon. So an emergency call to the Netherlands was necessary, to see if someone (my wife) could send 1000 dollars to us. Cees, during his field work, always had one major problem, he could not live without coffee and ... cigars. I remember that whenever he was out of cigars he used to ask everyone in the villages we came through to supply him with a few cigars (which was not always that easy ...). One of his Ecuadorian colleagues, the late Dr. Jaime Jaramillo, very aptly nicknamed Cees 'Doctor Cigaro'.

With the death of Cees, one of the Last Mohicans passed away. Throughout his long career he gained a vast and unparalleled knowledge of the huge family Moraceae, and of the genus Ficus in particular. He could identify even the tiniest leaf fragments. It is unlikely that this achievement is ever going to be equalled by anybody, and particularly so in a time that favours short-time projects rather than the long-term work so essential for understanding large plant families. We all shall miss Cees very much.

PaUl MaAs

\section{Projeto Flora Amazônica and The New York Botanical Garden}

Kees Berg's long relationship with The New York Botanical Garden (NYBG) began in 1977 when he participated in one of the two parallel expeditions that inaugurated Projeto Flora Amazônica (PFA), part of Brazil's ambitious plan to document its vast plant diversity. Over more than ten years, most of the financial support for PFA came from the U.S. National Science Foundation, and the non-Brazilian participation was coordinated by Ghillean Prance, curator and later Vice President for Botanical Science at NYBG. Kees' expedition included Prance, Antônio Sérgio da Silva (Brazilian counterpart), Michael Balick (then a graduate student and now director of the Institute of Economic Botany at NYBG), Bruce W. Nelson (now an ecologist at INPA in Manaus), and two tree-climbing mateiros or woodsmen, Mario R. dos Santos and Raimundo P. Bahia (well-known as 'Doca'). During October-December 1977, the expedition collected plants in the Serra dos Carajás, along the Transamazon Highway, around Tucuruí, in the Serra do Cachimbo, and along the Santarém-Cuiabá Highway. The expedition produced 1921 numbers, including 100 collections of palms.

For more than 40 years, Kees was appreciated by his colleagues at NYBG for sharing his rich knowledge of botany by identifying specimens, training students, publishing monographs, and contributing treatments of his plant families to many floristic projects. Probably his most important contribution to NYBG and to the botanical community overall were his treatments in his groups of expertise for these monographic and floristic projects, among others:

Flora Neotropica: Monographs for the Organization for Flora Neotropica, based at NYBG: Olmedieae and Brosimeae (Moraceae) in 1972; Coussapoa and Pourouma (Cecropiaceae) in 1990; Moreae, Artocarpeae and Dorstenia (Moraceae) in 2001; and Cecropia (Cecropiaceae) in 2005; he submitted his treatment of Ficus to Flora Neotropica just before his death. The Moraceae, Cecropiaceae, and Urticaceae for the Guide to the Vascular Plants of Central French Guiana. Those families plus the Ulmaceae for the First Catalogue of the Flora of Acre, Brazil.

Another service that Kees provided to NYBG botanists was the identification of nearly all of our collections of Moraceae (including Cecropiaceae), Urticaceae and Ulmaceae, which has greatly increased the scientific value of our collections. NYBGs institutional database has over 3200 identifications made by Kees over the years, but unquestionably the NY herbarium contains many more, because not all of its specimens are yet databased.

Curators at NYBG are grateful for the nearly 40 years of collaboration with Cornelis Berg, not only for the improvements he made to our collections and the intellectual contributions he made to our publication program, but also because of the close friendships that he maintained with many of our staff. He will be sorely missed, but he will continue to inspire everyone here who had the privilege of knowing him.

Douglas Daly and Scott MoRI

\section{Bergen, Norway}

[After Utrecht, a second phase in Cees' career was his professorship in Norway.] One of the first things Kees said to me in the process leading to his employment at Milde (Norway, near Bergen) in 1985 was: "I am an old tree, and they are difficult to transplant". Nevertheless the transplantation took place, and as predicted, he had a rather difficult process adapting to the new environment and the new language, but he took that challenge with restraint.

Frankly, the conditions at Milde were far from ideal for research of the tropical genus Ficus and its relatives. Nevertheless, Kees continued to work indefatigably on this enormous and very complicated group of plants, which are so important in the tropics, and with the help of a generous gift from our benefactor, Bjarne Rieber, he managed to establish a greenhouse to grow them. He had about 200 different species in cultivation.

This being solved, a much more difficult task remained: to adapt to the rather complicated management of the organization, one which was an enduring mystery to him, and for that reason I was given the task to assist him. We had many long discussions, and somehow found ways through this jungle. I cannot claim they were easy talks, but Kees had an unusually friendly persistence, which I liked, so we never really clashed, even when we disagreed.

I particularly remember that, to my surprise, he was very keen on establishing a collection of native Norwegian trees, an idea that had not previously crossed our minds - we were primarily engaged in finding foreign woody plants for Norwegian gardens. But certainly he was correct in suggesting that the Norwegian Arboretum should also take an interest in our native trees!

$\mathrm{He}$ also engaged in the relationship with the Friends of the Arboretum and soon after he arrived started to write a Newsletter which under his successor Per H. Salvesen has developed into the important journal Årringen, issued yearly, in which we present results from our collections to the general public. This close relationship with the Friends led to the establishment of a heather garden, which was donated in 1996, and which still 
is run by the Friends. This garden was an enjoyment to him, as well as to all of us.

After his retirement in 2005, Kees returned to the Netherlands, but he was a frequent visitor to Bergen - surely the old tree had developed some Norwegian roots. He usually came about midsummer, when also visiting his daughter Hendrieke at Voss. He then filled the tables in the BG herbarium with 2000-3 000 specimens, which now form a comprehensive, well-identified collection preserved for future generations to study - of particular importance since the tropical forests are disappearing quickly.

But this summer in 2012 we missed him, he was too ill to travel, though he still steadily worked on his revision of Ficus. In his last letter, which we received a few weeks before his death, he was concerned about a loan, which was needed quickly for drawings (by his daughter Hendrieke) for a paper he had nearly finished, because he knew that his days were numbered. He was certainly one of the most dedicated and industrious botanists I have known.

The old tree has fallen, but the seeds he has spread, will grow! PER M. JøRgensen

\section{Leiden, The Netherlands}

Back in the Netherlands Cees continued his work on Moraceae. The first time I met him in the Leiden herbarium, I vaguely remembered that I had seen him when I was still an MSc student, working on the ecology of tsetse flies in Ivory Coast. My supervisor was Prof. Dr. Koos Wiebes, a specialist in fig wasps. Wiebes announced that he would come for field work to the Ivory Coast and while driving to the expedition site he would visit me and he would be accompanied by a colleague, which indeed was Cees Berg. Together they worked on the interaction between figs and wasps, resulting in a book about the African species (Berg \& Wiebes, 1992). Leiden is for many taxonomists synonymous with Flora Malesiana, but Asia had never been a focus for Cees before, probably because Corner, another world expert on Moraceae, revised the Malesian Moraceae. Corner had produced a manuscript on the Malesian Moraceae, but disagreement with Van Steenis (editor of Flora Malesiana) about several species concepts stalled publication of the Moraceae. We were happy that we could interest Cees in revising the Malesian Moraceae, using Corner's manuscript as a basis. He consulted thousands of specimens during a few sabbatical leaves, and quickly produced two big volumes, one on Ficus (2005) and one on the remaining Moraceae (2006). The editors of local Asian floras now became aware of Cees' expertise and invited him to help with their flora treatments as well. He liked working on the Thai Moraceae. This took quite some time, but it allowed him to visit the country several times. At the time of his death, Cees was still supervisor of a Thai PhD student, Bhanumas Chantarasuwan (see below) working on a group of figs. Cees based his work on a morphological species concept, but he was open to suggestions based on molecular work if they would fit in with his concepts. (Based on molecular work the Cecropiaceae, newly described by Cees, were synonymised again with the Urticaceae.) Cees closely collaborated with Finn Kjellberg and his group in Montpellier (France), often providing them with his insights and with material for DNA analysis. Cees was certainly a person who liked to travel; he visited and did field work in almost all the tropical countries of Africa and South America. In Asia, he visited southern China and Thailand. Only after retirement did he return once to his land of birth, now called Indonesia.

Peter van Welzen

\section{Collecting in Acre, Brazil}

The state of Acre, Brazil in south-western Amazonia is honoured to have been the site of Dr. Cornelis C. Berg's last botanical expedition, in April 2010. Given the high diversity of Moraceae in Acre, he was one of the key botanists invited to participate in the Mobilizing Taxonomic Specialists for Acre-project, developed by the collaborative research program between the New York Botanical Garden and the Universidade Federal do Acre (UFAC) to advance our knowledge of that region's most important plant groups.

He joined the field team of UFACs Laboratório de Botânica e Ecologia Vegetal, which at the time consisted of Flávio Obermüller, Marcos Silveira, Herison Medeiros, Wendeson Castro, Edilson Consuelo de Oliveira, Lívia Souza and Heloisa Polary. The group visited several localities: the Riozinho do Andirá, Seringal Cachoeira, Fazenda Catuaba, Reserva Florestal Humaitá, Rio Iquirí, and the Vila do V in six municipalities (Rio Branco, Sena Madureira, Bujari, Porto Acre, Senador Guiomard and Xapuri) in the eastern part of the state. The expedition produced more than 400 collections, the vast majority of them in the families of Dr. Berg's expertise. Before and after the field work, he annotated virtually all the UFAC herbarium's specimens in those plant groups.

His work contributed significantly to our knowledge of the Acre flora, adding two new genus records and 25 new species records for the state, and among those eight new records for Brazil. Undoubtedly, if he had had more time, he would have added a number of species new to science from the Acre flora, considering that 18 or nearly half of his Ficus collections from that trip remained undetermined.

During his brief visit to Acre, 'Berg' (as he was dubbed there) made a lasting impression on everyone he met. He will be remembered in Acre with fondness and great respect.

FLÁvio ObermülleR and Douglas Daly

\section{Ficus classification}

I first met Kees in 1983, for the first fig meeting. Among others, those in attendance included the late Koos Wiebes and Jacob Galil. A young generation of scientists had just started to work on the fig classification, early 1980. They included Allen Herre, Judith Bronstein and me. Steve Compton soon joined the group, and others would follow. At that time, publications on fig-fig wasp interactions were few. Only two papers on the subject in indexed journals appeared that year, one by Baijnath et al. and one by Berg. Berg's paper 'Floral differentiation and dioecism in Ficus (Moraceae)' raised a question that would haunt him until his last days: how can monoecious figs produce short-styled and long-styled pistillate flowers mixed together within the same fig? He thought the answer could come from histological studies. "There might be [histological] methods better than Wouter [Verkerke] had at his disposal to supply answers." Indeed, an answer to his concern may have been provided by the team of Simone Teixeira de Pádua at the last fig meeting. The atypical asclepiate style development observed in Ficus could be the morphological key. The questions around pistillate flower specialization made the figs of monoecious subsection Petenense of section Pharmacosycea particularly fascinating to him: the stigmas of short-styled and long-styled flowers reach different heights. When I sent him a picture of a receptive fig of Ficus adhatodifolia, with the flower arrangement of subsection Petenense, he answered "Dear Finn, in all F. adhatodifolia material the interior of the figs looks like those of all other members of subsection Bergianae. I hope that you collected some material, figs + leaves, of this interesting plant which is not so systematist friendly." In fact, this F. adhatodifolia was not atypical, but the picture was taken in the field, from fresh material, at receptivity 
when traits were obvious. In the herbarium with figs later in development, the trait could no longer be seen.

There was quite a bit of frustration in the relationship between fig biologists and the taxonomists during the last two decades of the 20th century. The biologists generally worked very locally and they could see very clear differences among entities that Kees did not recognize in his floristic treatments. The biologist presented his points and Kees put up a broad smile and, apparently, did not change his perspective. The disconnection was partly due to the slow pace of global taxonomic revision. It was also due to the difference between a local perspective and a range-wide perspective. But these were not the only reasons. Kees had decided that he would only recognize species that he could distinguish based on sterile material in herbarium collections. And that is a hard challenge, especially in section Malvanthera. Therefore, for scientists working on New Guinea, his revision of section Malvanthera was a nightmare. The species group of Ficus americana provides a more interesting case: "The fact that "guianensis" (highly variable), "greifiana", and "subapiculata" co-occur suggests that they are species rather than subspecies. I have not been able to find vegetative characters to distinguish them from each other and from material outside the Amazon basin." Indeed, in the herbarium in Cayenne, most of the samples are relatively easy to assign to species (if they bear figs), but without figs it becomes really complex, even out in the forest. Further samples from some places look atypical. In fact, we are within a species complex that probably presents quite a bit of geographic differentiation in forms. Calling this a species complex is probably the appropriate taxonomic treatment, pending population genetics studies. Nevertheless, for the field biologist, the lack of clear names for what looked like highly distinct forms in coastal French Guiana was frustrating.

In addition, you often needed a trained eye to detect Kees' doubts in his taxonomic revisions. And they were many and most of them were legitimate. About the Ficus pertusa complex he wrote me "these species complexes have been a headache". And more generally about Brazil "by the way, did you ever receive my headache publication Ilicifolia 5 , in which there is a survey of the extra-Amazonian Ficus species?".

The paths of taxonomists and biologists began to converge seriously with the start of the 21 st century. Biologists travelled more, saw more variation, began to do some population genetics and hence began to understand better the taxonomy and taxonomic problems. Reciprocally, the biologists provided information that helped the taxonomist to advance. A good photograph of fresh material shortened the discussion.

In his later years, after having clarified his global vision of figs, Kees began to enter more in detail into species groups, and when possible added some observations made in the field. "The auriculata-oligodon-hainanensis assemblage is not easy to disentangle - see my paper in Thai Forest Bulletin 35 (2007). During my recent visit to Thailand I started to change my opinion, but do not know how to tackle the problem. It is not only a matter of inadequate herbarium material. Also in the field the situations are complex." Indeed, population genetic studies of this species group show that it is a complex with variation, hybrids, and introgression, but also clearly defined entities that coexist locally. For that species group Kees had reached the bottom of the question and understood where population genetic studies should take over.

Another important development was the advances in fig wasp collecting and knowledge of their taxonomy. Berg and Wiebes published a remarkable volume in 1992, African fig trees and fig wasps. It covered all African fig species and quite a number of their pollinating wasps. It raised hopes within the fig biologist community that figs and fig wasps from other parts of the world would soon be properly described and properly arranged into well-organized taxonomic groups. This has yet to happen. Wiebes finalized his taxonomic treatment of The Indo-Australian Agaoninae (pollinators of figs) in 1994, and the one on The New World Agaoninae (pollinators of figs) in 1995. Kees took much more time. He published his treatment for Flora Malesiana in 2005. His treatment of the flora of the Americas was not yet published by the time of his death. However, Kees' treatments were much more thorough and as objective as possible. He did not take hints from the classification of associated pollinating wasps and from molecular results. In an interesting twist, Kees classified F. menabeensis (and F. humbertii) from Madagascar as belonging to section Conosycea, suggesting an Asian origin, while Wiebes thought the pollinator belonged to genus Platyscapa, which could have come from Africa as was the case for all other figs and fig wasps from Madagascar. I have always assumed that Wiebes named the species Platyscapa bergi as an inside joke, convinced that history would prove Kees to be wrong. Current developments suggest Kees was right and Wiebes wrong. In another interesting twist, Kees never believed the molecular results that have pervaded fig literature since 1996; these separated section Pharmacosycea and its pollinators from section Oreosycea and its pollinators. The results were simply not acceptable to him, and he just put up a large smile, as usual. Recent results suggest he may have been right. Highly intensive collection of fig wasps only began recently. Someone like Astrid Cruaud saw more Ficus species in the field in her three years of $\mathrm{PhD}$ than Corner ever saw in his life and Jean-Yves Rasplus, one of the two current fig wasp taxonomists with Simon van Noort, has seen huge numbers of fig species, especially during the last 10 years. China has woken up, especially in Yunnan, a region that could be the cradle of Ficus diversification. This means that it has been only recently that fig wasp taxonomy has made new advances, with many more years to go before a global revision is done, and it is only recently that fig scientists have really looked at fig variation among islands, countries or continents.

Someone told me a few years ago that you can only tell a good taxonomist at the end of his life. Kees was a good taxonomist. Quite a number of times he defended positions that seemed backward but turned out to be true. The last few years, a few other fig taxonomists have seen enough fig species in the field from all over the world to help Kees finalize his taxonomic perceptions. These years were few, but Kees enjoyed them, because he was no longer the only field botanist who understood figs based on field work.

FinN KJeLLberg

\section{Molecular work}

Cees was sceptical about the ability of DNA-sequence-based phylogenies to uncover the true relationships of figs, but - as always - he welcomed anyone who contributed to an understanding about any aspect of Ficus. Embarking on a quest for discovering the global phylogeny of Ficus, I first contacted Cees in 2002 to ask if he would support my funding applications as an expert on the classification of Ficus. He kindly wrote back the same day and offered his assistance as well as access to his extensive living collections in Milde, which I visited for a pleasant couple of days in 2003. I since met him several times when he visited the herbaria at Kew and Minnesota where I worked during my postdoctoral years. He was always very helpful, checking my identifications and commenting on the results of the phylogenetic analyses, and he always had time for to discuss future research needs over a nice meal accompanied by a good beer. He was particularly happy about the possibility of the DNA-based work to enlighten the large and difficult 
Neotropical section Americana, which he finished revising just before his death. However, he was very sceptical about some of the infrageneric relationships suggested by the molecular data and wondered about the limitations and methodological errors. When offered co-authorship for his help and comments on the first global phylogeny published in 2005, he kindly refused with a smile and a twinkle of his eye, because he preferred to keep the right to criticise it afterwards. In Flora Malesiana, he largely ignored the molecular suggestions of relationships; I guess he found it too difficult to decide which of the results were well-supported and which were only preliminary hypotheses, and without question, we are still struggling to sort out the infrageneric relationships of Ficus and even the origin of the figs based on molecular data. Berg was a great morphologist and has inspired us to pursue the molecular work in even more detail, especially when DNA suggests obvious conflicts with relationships well supported by morphology. As Berg said, "it has to make sense, you can't just say that swallows are not birds". And so the white crane has himself departed, but his love of Ficus, supportive attitude, and persistence and insistence on making sense of it all continues.

NinA RøNSTED

\section{The Great Supervisor}

I first met Prof. Berg in 2003 in the Thai Forest Herbarium in Bangkok, when he visited Thailand to join the Flora of Thailand project. Two days later, we went on a field trip to the Bala forest, a part of Hala-Bala Wildlife Sanctuary, the most southern part of Thailand in Narathiwat province. Our first stop was at Wanakorn National Park, Prachuap Khiri Khan province, where we found Ficus curtipes Corner, a species very similar to F. callophylla Blume, which confused me. Prof. Berg kindly pointed out the distinguishing characters. This was the first time that he instructed me about Ficus. During the second day of the trip (Kha Chong Botanic Garden, Trang province) we collected many fig species and Prof. Berg still happily taught me about all the species. And again, in Bala forest, he was never too tired to share his great knowledge and experience. This trip was the most impressive course I ever followed.

In 2009, I came to Leiden (The Netherlands) for my PhD study on Ficus, and Prof. Berg immediately started to teach me about fig flowers, species description, nomenclature and everything

\section{PUBLICATIONS BY DR CORNELIS CHRISTIAAN BERG}

compiled by C.W.J. Lut

\section{6}

- (with Segal S) De Pinksterbloem in Nederland. Gorteria 3: 77-86.

1967

- Cytotaxonomic studies in Cardamine pratensis L. in the Netherlands. Acta Botanica Neerlandica 15: 683-689.

1968

- Taxonomic and morphological notes on Clarisia (Moraceae). Acta Botanica Neerlandica 17: 309-312.

- Proposal to add Ferolia Aublet to the names to be rejected against 1957. Brosimum Swartz nom. cons. Taxon 17: 731 .

1969

- New taxa and combinations in the Neotropical Olmedieae. Acta Botanica Neerlandica 18: 462-465.

1970

- New taxa and combinations in the genus Brosimum (Moraceae). Acta Botanica Neerlandica 19: 326-328.

\section{2}

- A new species in Helianthostylis (Moraceae). Acta Botanica Neerlandica 21: $99-101$ else one has to know about the genus. We met for discussions every week during which we usually talked about my work but sometimes also about his work. He always came to my room with specimens or papers, which stimulated our discussions. In 2011, when I visited Montpellier (France) for molecular lab work, he continually sent me leaf samples and he never forgot to make suggestions for improving my research. After my return to Leiden in February this year, his health started to deteriorate, but he still came to the herbarium to work. The last letter he sent me was on 11 May 2012, in which he informed me about his illness. Prof. Berg even went to Berlin after chemotherapy had improved his abilities somewhat, but soon after that he became quite ill again. During his illness he still worked very hard, so the last thing I learned from him is "illness should be no excuse not to do anything". Dear Prof. Berg, thank you very much for what I have learned from you, and many thanks for having supervised my research on figs.

Bhanumas ChantarasuWan

\section{Honours}

We knew Cees as a silent, hard-working man who never took part in social events like coffee breaks or drinks. This is obviously a choice he made between social contacts and sufficient working hours in the herbarium as his commuting time was long. Till his death, he tried to visit Leiden as much as possible, but like in Norway, he missed his last appointment. We not only treasure him as a hard-working person, but also as a very friendly and helpful person. Although he had no teaching obligations in Leiden, he still motivated students to help him revise the fig species of the Solomon Islands. We admire the way he made all arrangements for after his death: the list of persons who should be notified, who should 'clean' his desk, etc. Cees was really a banyan tree among taxonomists and he will be dearly remembered.

One Moraceae was named in honour of Cees, Dorstenia bergiana Hijman, and the name of a fig wasp, Platyscapa bergi Wiebes, is a tribute to his contributions to fig-fig wasp interactions and relationships. Cees newly described or made new combinations for 318 taxa in the Moraceae and Cecropiaceae and for one in the Boraginaceae, a subspecies of Myosotis, M. palustris (L.) Nathh. subsp. nemorosa (Besser) C.C.Berg \& Kaastra, a result of his polyploidy interest.

Peter van Welzen
- Flora Neotropica Monograph 7. Olmedieae and Brosimeae (Moraceae). 228 pp. New York. (Reprint 1985.)

- A new species of Cecropia (Moraceae). Acta Botanica Neerlandica 21: 655-656.

1973

- (with Kaastra RC) Myosotis palustris en M. laxa in Nederland. Gorteria 6: 141-150.

- Some remarks on the classification and differentiation of Moraceae. Mededelingen van het Botanisch Museum en Herbarium van de Rijksuniversiteit te Utrecht 386. $10 \mathrm{pp}$.

1975

- (with DeWolf GP) Moraceae. In: Lanjouw J, Stoffers AL, Flora of Suriname. 5: 173-299. Leiden.

1977

- (with Hijman MEE) A precursor to the treatment of Dorstenia for the Floras of Cameroun and Gabon. Adansonia, sér. 2, 16: 415-443.

- The Castilleae, a tribe of the Moraceae, renamed and redefined due to the exclusion of the type genus Olmedia from the "Olmedieae". Acta Botanica Neerlandica 26: 73-82. 
- Abscission of anthers in Cecropia Loefl. Acta Botanica Neerlandica 26: 417-419.

- Cecropia purpurascens, a new species of Brazilian Amazonia. Acta Amazonica 7: 185-188.

- Urticales, their differentiation and systematic position. In: Kubitzki K (ed), Flowering plants - Evolution and classification of higher categories. Plant Systematics and Evolution, Suppl. 1: 349-374.

- Revisions of African Moraceae (excl. Dorstenia, Ficus, Musanga and Myrianthus). Bulletin du Jardin Botanique National de Belgique 47: 267-407.

1978

- Revision of Dorstenia sect. Nothodorstenia (Moraceae). Botaniska Notiser 131: 53-66

- Cecropiaceae a new family of the Urticales. Taxon 27: 39-44.

- New Amazonian species: Coussapoa prancei and Perebea mennegae (Moraceae). Acta Botanica Neerlandica 27: 11-15.

- (with Mennega EA, Tolsma J) A new species of Peperomia (Piperaceae). Acta Botanica Neerlandica 27: 79-81.

- Espécies de Cecropia da Amazônia Brasileira. Acta Amazonica 8: 149 182.

- Index of exsiccatae of revised taxa of African Moraceae. Utrecht. 26 pp.

- Notulae: Revisions of African Moraceae (excl. Dorstenia, Ficus, Musanga and Myrianthus): corrections and additions. Bulletin du Jardin Botanique National de Belgique 48: 466-468.

1980

- Three new African Ficus species and a comment on Ficus gnaphalocarpa (Moraceae). Adansonia, sér. 2, 20: 263-272.

- Moraceae. In: Stoffers AL (ed), Flora of the Netherlands Antilles 2: 111-120. Utrecht

1981

- A new species of Ficus (Moraceae) from Costa Rica. Acta Botanica Neerlandica 30: 231-233.

- (with Simonis E) The Ficus flora of Venezuela: Five species complexes discussed and two new species described. Ernstia 6: 1-12.

- An exceptional new species of Cecropia (Moraceae) from Ecuador. Nordic Journal of Botany 1: 485-487.

- The reinstatement of the West African Ficus lutea Vahl (Moraceae). Kew Bulletin 36: 597-598.

1982

- The reinstatement of the genus Milicia Sim (Moraceae). Bulletin du Jardin Botanique National de Belgique 52: 225-229.

- (with Van Leeuwen RWJ) The Dorstenia species (Moraceae) of northwestern tropical America. Proceedings, Koninklijke Nederlandse Akademie van Wetenschappen. Series C, Biological and medical sciences. Amsterdam 85: 29-39.

- (with Kooy F) Three new species of Pourouma (Cecropiaceae) of the Guiana region. Brittonia 33: 36-41.

- (with Akkermans RWAP) New species and combinations in Coussapoa (Cecropiaceae) and keys to its species. Proceedings, Koninklijke Nederlandse Akademie van Wetenschappen. Series C, Biological and medical sciences. Amsterdam 85: 441-471.

- (with Van Heusden ECH) Moraceae. In: Flora of Trinidad and Tobago 2: 722-749.

1983

- (with Den Hollander G) Studies on the flora of the Guianas 4. A new species of Apinagia (Podostemonaceae) and a key to the Apinagia species of Suriname. Acta Botanica Neerlandica 32: 223-226.

- A new species of Coussapoa (Cecropiaceae) from Peru. Proceedings, Koninklijke Nederlandse Akademie van Wetenschappen. Series C, Biological and medical sciences. Amsterdam 86: 305-307.

- Dispersal and distribution in Urticales - an outline. In: Kubitzki K (ed), Dispersal and distribution. Sonderbände des Naturwissenschaftlichen Vereins in Hamburg 7: 19-229.

1984

- (with Hijman MEE, Weerdenburg JAC) Flore du Gabon 26. Moracées. Paris. 276 pp.

- Moraceae. In: Brunel JF, Hiepko P, Scholz H (eds), Flore analytique du Togo. Englera 4: 355-366.

- Floral differentiation and dioecism in Ficus (Moraceae). In: Kjellberg F, Valdeyron $G$ (eds), Mini symposium: Figs and fig insects: 15-28. CNRSCentre Louis Emberger, Montpellier.

- Differentiation of fruitlets of Ficus, especially of subg. Urostigma sect. Galoglychia. In: Kjellberg F, Valdeyron G (eds), Mini symposium: Figs and fig insects: 29-33. CNRSCentre Louis Emberger, Montpellier.
- (with Vázquez Avila M, Kooy F) Ficus species of Brazilian Amazonia and the Guianas. (Contribuiçoes do Projecto Flora Amazônica 1). Acta Amazonica 14 (suplemento): 159-194.

- (with Vázquez Avila M, Kooy F) New taxa of South American Ficus. (Contribuiçoes do Projecto Flora Amazônica 1). Acta Amazonica 14 (suplemento): 195-213.

1985

- (with Michaloud G, Michaloud-Pelletier S, Wiebes JT) The co-occurrence of two pollinating species of fig wasp and one species of fig. Proceedings, Koninklijke Nederlandse Akademie van Wetenschappen. Series C, Biological and medical sciences. Amsterdam 88: 93-119.

- (with Carauta JPP) Two new species of Dorstenia (Moraceae) from East Brazil. Proceedings, Koninklijke Nederlandse Akademie van Wetenschappen. Series C, Biological and medical sciences. Amsterdam 88: 261-265.

- (with Akkermans RWAP) Studies on the Flora of the Guianas 14. New taxa and combinations in Sorocea (Moraceae) and a key to its species. Proceedings, Koninklijke Nederlandse Akademie van Wetenschappen. Series C, Biological and medical sciences. Amsterdam 88: 381-394.

- Studies on the Flora of the Guianas 15. A new species of Cecropia (Cecropiaceae) from French Guiana. Bulletin du Muséum national d'Histoire naturelle. Section B, Adansonia: Botanique phytochimie. Paris. Sér. 4, 7 (Sect. B, Adansonia No. 3): 255-258.

- Studies on the Flora of the Guianas 16. A new species of Pilea (Urticaceae) from French Guiana. Bulletin du Muséum national d'Histoire naturelle. Section B, Adansonia: Botanique phytochimie. Paris. Sér. 4, 7 (sect. B, Adansonia No. 4): 429-431.

- (with Hijman MEE, Weerdenburg JAC) Flore du Cameroun 28. Moracées (incl. Cecropiacées). Yaoundé. 298 pp.

- (with Van Heusden ECH) Flore des Mascareignes, Fam. 164 (Moracées). Port Louis, Mauritius. $21 \mathrm{pp}$.

1986

- The Ficus species (Moraceae) of Madagascar and the Comoro Islands. Bulletin du Muséum national d'Histoire naturelle. Section B, Adansonia: Botanique phytochimie. Paris. Sér. 4, 8 (Sect. B, Adansonia No. 1): 17-55.

- (with Carauta JPP) Cecropia (Cecropiaceae) no Brasil ao Sul da Bacia Amazônica. Albertoa 1: 312. (Reprint 1996.)

- Subdivisions of Ficus subg. Urostigma sect. Galoglychia (Moraceae). Proceedings, Koninklijke Nederlandse Akademie van Wetenschappen. Series C, Biological and medical sciences. Amsterdam 89: 121-127.

- (with Wendt T) A new species of Dorstenia (Moraceae) from Mexico. Proceedings, Koninklijke Nederlandse Akademie van Wetenschappen. Series C, Biological and medical sciences. Amsterdam 89: 129-132.

- Studies on the Flora of the Guianas 20. The Dorstenia species (Moraceae) of southeastern tropical America. Proceedings, Koninklijke Nederlandse Akademie van Wetenschappen. Series C, Biological and medical sciences. Amsterdam 89: 133-146.

- (with Den Hollander G) Studies on the Flora of the Guianas 21. Mabea species (Euphorbiaceae) of the Guianas - a precursor. Proceedings, Koninklijke Nederlandse Akademie van Wetenschappen. Series C, Biological and medical sciences. Amsterdam 89: 147-157.

- The delimitation and subdivision of the genus Maclura (Moraceae). Proceedings, Koninklijke Nederlandse Akademie van Wetenschappen. Series C, Biological and medical sciences. Amsterdam 89: 241-247.

\section{8}

- New taxa and combinations in Ficus (Moraceae) of Africa. Kew Bulletin 43: 77-97.

- (with Van Heusden ECH) New taxa and combinations in Pourouma (Cecropiaceae). Proceedings, Koninklijke Nederlandse Akademie van Wetenschappen. Series C, Biological and medical sciences. Amsterdam 91: 105-116.

- The genera Trophis and Streblus (Moraceae) remodelled. Proceedings, Koninklijke Nederlandse Akademie van Wetenschappen. Series C, Biological and medical sciences. Amsterdam 91: 345-362.

- The Norwegian Arboretum at Milde. Newsletter European Mediterranean Division of I.A.B.G. 9: 15-16.

1989

- (with Hijman MEE) Moraceae and Cecropiaceae. In: Polhill RM (ed), Flora of Tropical East Africa. 95 pp. Rotterdam / Brookfield.

- Classification and distribution of Ficus. In: Comparative biology of figs. Experientia 45: 605-611.

- Systematics and phylogeny of the Urticales. In: Crane PR, Blackmore $\mathrm{S}$ (eds), Evolution, systematics, and fossil history of the Hamamelidae. Oxford. Vol. 2. 'Higher' Hamamelidae: 193-220.

- Pourouma herrerensis C.C.Berg, a new species of Cecropiaceae from Amazonian Peru. Contribution to the study of the flora and vegetation of Peruvian Amazonia. XV. Candollea 44: 513-516. 
- De vele gezichten van de tuin. In: Botanische tuinen: een bijzondere wereld aan planten. Botanische Tuinen Utrecht 350 jaar (1639-1989): 17-25. Ede / Antwerpen.

\section{0}

- New species of Coussapoa and Pourouma. Brittonia 42: 59-65.

- (with Akkermans RWAP, Van Heusden ECH) Flora Neotropica, Monograph 51. Cecropiaceae: Coussapoa and Pourouma, with an introduction to the family. 208 pp. New York.

- Annotated checklist of Ficus species of the African floristic region, with special reference and a key to the taxa of Southern Africa. Kirkia 13: 253-291.

- Distribution of African taxa of Ficus (Moraceae). Mitteilungen aus dem Institut für Allgemeine Botanik Hamburg 23a: 401-405.

- Reproduction and evolution in Ficus (Moraceae): Traits connected with the adequate rearing of pollinators. In: Gottsberger GK, Prance GT (eds), Reproductive biology and evolution of tropical woody Angiosperms. Memoirs of the New York Botanical Garden 55: 169-185.

- Differentiation of flowers and inflorescences of Urticales in relation to their protection against breeding insects and to pollination. Sommerfeltia 11: 13-34.

\section{1}

- (with Hijman MEE) Moraceae and Cecropiaceae. In: Launert E, Pope GV (eds), Flora Zambesiaca 9, 6: 13-78. London.

\section{2}

- Ulmaceae, Moraceae, Cecropiaceae, Urticaceae and Casuarinaceae. In: Görts-van Rijn ARA (ed), Flora of the Guianas Ser. A., Fasc. 11: 222 pp. Koenigstein. (incl.: Wood and Timber, by Ter Welle BJH, Bonsen K, Détienne P. pp. 141-191).

- (with Wiebes JT) African fig trees and fig wasps. 298 pp. Amsterdam / Oxford / New York / Tokyo.

- Cecropiaceae, Moraceae, Ulmaceae and Urticaceae. In: Bogan J, Funk V, Kelloff C, Hoff M, Cremers G, Feuillet C (eds), Checklist of plants of the Guianas (Guyana, Surinam, French Guiana). Georgetown, Guyana.

1993

- (with Franco Rosselli P) Cecropiaceae. In: Harling G, Andersson L (eds), Flora of Ecuador 27A. 109 pp. Arlöv.

1996

- Moraceae Guineae Aequatorialis nonnullae. Fontqueria 44: 93-105.

- (with Franco Rosselli P) New taxa and combinations in Moraceae and Cecropiaceae from Central and South America. Novon 6: 230-252.

- (with Carauta JPP) Cecropia (Cecropiaceae) no Brasil, ao sul da bacia Amazonica. Albertoa 4, 16: 213-221.

- (with Compton SG, Wiebes JT) The biology of fig trees and their associated animals. Journal of Biogeography 23: 405-407.

1997

- Cecropiaceae, Moraceae, Ulmaceae and Urticaceae. In: Bogan J, Funk V, Kelloff C, Hoff M, Cremers G, Feuillet C (eds), Checklist of plants of the Guianas (Guyana, Surinam, French Guiana), 2nd ed. Georgetown, Guyana.

- (with Franco Rosselli P) Distributional patterns of Cecropia (Cecropiaceae), a panbiographic analysis. Caldasia 19: 285-296.

1998

- Moraceae (excl. Ficus). In: Harling G, Andersson L (eds), Flora of Ecuador 60, 128 pp. Arlöv.

- Cecropiaceae. In: Berry PE, Holst BK, Yatskievych K (eds), Flora of the Venezuelan Guayana, Vol. 4 (Caesalpiniaceae-Ericaceae): 174-190. St. Louis.

- Cecropiacea, Moraceae, Ulmaceae and Urticaceae. In: Dubs B, Prodromus Florae Matogrossensis, Part I-II. The Botany of Mato Grosso, Series $B$, no.3. Küsnacht.

- Cecropiaceae. In: Friis IB, Vollesen KAJ (eds), Flora of the Sudan-Uganda border area East of the Nile. 1. Catalogue of vascular plants, 1st part. Biologiske Skrifter, det Kongelige Danske Videnskabernes Selskab 51, 1: 250.

- Phytogeography, systematics and diversification of African Moraceae compared with those of other tropical areas. In: Huxley CR, Lock JM, Cutler DF (eds), Chorology, taxonomy and ecology of the floras of Africa and Madagascar: 131-148. Kew.

- 'Slangeved' - en 'løvetann' blant neotropiske trær. Årringen 2: 87-92.

\section{9}

- (with Hijman MEE) The genus Dorstenia (Moraceae). Ilicifolia 2: 1-211.

- Ficus - mer enn bare en stor slekt. Årringen 3: 83-92.
- Cecropiaceae. In: Jørgensen PM, León-Yánez S (eds), Catalogue of the vascular of Ecuador. Monograph in systematic botany from the Missouri Botanical Garden 75: 390-392. St. Louis.

- Ficus mariae (Moraceae), nova espécie Sul-Americana. Bradea 7, 20 : 111-113.

- Moraceae. In: Jørgensen PM, León-Yánez S (eds), Catalogue of the vascular plants of Ecuador. Monograph in systematic botany from the Missouri Botanical Garden 75: 604-611. St. Louis.

- A new species of Ficus (Moraceae) from Bolivia and Peru. Brittonia 51: 395-397.

- (with Ribeiro JELdaS) UImaceae. In: Ribeiro JELdaS et al., Flora da Reserva Ducke: 195. INPA, Manaus.

- (with Ribeiro JELdaS) Moraceae. In: Ribeiro JELdaS et al., Flora da Reserva Ducke: 196-209. INPA, Manaus.

- (with Ribeiro JELdaS) Cecropiaceae. In: Ribeiro JELdaS et al., Flora da Reserva Ducke: 210-217. INPA, Manaus.

2000

- (with Simonis JE) Flora de Venezuela 16: Moraceae: 5-189 (indices: 250-269). Fundación Instituto Botánico de Venezuela "Dr. Tobias Lasser", Caracas.

- (with Simonis JE) Flora de Venezuela 16: Cecropiaceae: 191-249 (indices: 250-269). Fundación Instituto Botánico de Venezuela "Dr. Tobias Lasser", Caracas.

- Ficus corneriana, a new species of Ficus subg. Sycidium sect. Palaeomorphe (Moraceae) from the Solomon Islands. Blumea 45: 397-398.

- (with Dahlberg SV) A revision of Celtis subg. Mertensia (Ulmaceae) Brittonia 53: 66-81.

- Moraceae. Dendroflora 37: 14-19.

- Pollinering i slekten fiken (Ficus). Årringen 4: 54-60.

2001

- Moraceae. In: Berry PE, Holst BK, Yatskievych K (eds), Flora of the Venezuelan Guayana 6 (Liliaceae-Myrsinaceae): 693-729. St. Louis.

- A new species of Cecropia (Cecropiaceae) from Colombia. Caldasia 23 77-79.

- Flora Neotropica Monograph 83: Moreae, Artocarpeae and Dorstenia (Moraceae). With introductions to the family and Ficus and with additions and corrections to Flora Neotropica Monograph 7, 346 pp. New York.

2002

- (with Hijman MEE) Dorstenia. In: Eggli U (ed), Illustrated handbook of succulent plants: Dicotyledons: 314-322. Springer Verlag.

- Ficus. In: Eggli U (ed), Illustrated handbook of succulent plants: Dicotyledons: 322-323. Springer Verlag.

- Ficus subgenus Pharmacosycea section Oreosycea (Moraceae) in the Solomon Islands, Fiji, and the New Hebrides. Blumea 47: 299-314.

- Ficus baola, a new species of Ficus subgenus Urostigma section Malvanthera (Moraceae) from the Solomon Islands. Blumea 47: 315-317.

- Moraceae. In: Mori SA et al., Guide to the vascular plants of central French Guiana. Memoirs of the New York Botanical Garden 76: 515-525.

- Cecropiaceae. In: Mori SA et al., Guide to the vascular plants of Central French Guiana. Memoirs of the New York Botanical Garden 76: 194-198.

- Ulmaceae. In: Mori SA et al., Guide to the vascular plants of Central French Guiana. Memoirs of the New York Botanical Garden 76: 720-722.

- Urticaceae. In: Mori SA et al., Guide to the vascular plants of Central French Guiana. Memoirs of the New York Botanical Garden 76: 722-724.

- An account on the Cecropia species (Cecropiaceae) of Peru. Caldasia 24: $229-238$.

2003

- Flora Malesiana precursor for the treatment of Moraceae 1: The main subdivisions of Ficus: the subgenera. Blumea 48: 167-178.

- Broussonetia papyrifera (L.) L'Hér. ex Vent. In: Brink M, Escobin RP (eds), Plant Resources of South-Asia 17, Fibre plants: 91-95.

- (with Carauta JPP) New species of Ficus (Moraceae) from Brazil. Brittonia 54: 236-250.

- Flora Malesiana precursor for the treatment of Moraceae 2: Ficus subgenus Pharmacosycea section Oreosycea. Blumea 48: 289-301.

- (1587-1590) Proposals to conserve the names of Ficus citrifolia against F. caribaea, F. maxima with a conserved type, F. aurea against F. ciliolosa, and F. americana against F. perforata (Moraceae). Taxon 52: 368-370.

- (with Villavicencio X) A new species of Ficus and a new species of Pseudolmedia (Moraceae) from Bolivia. Revista de la Sociedad Boliviana de Botánica 4: 75-79.

- (with Villavicencio X) El género Ficus en Bolivia. Revista de la Sociedad Boliviana de Botánica 4: 81-129.

- Flora Malesiana precursor for the treatment of Moraceae 2: Ficus subgenus Pharmacosycea section Oreosycea. Blumea 48: 289-301. 
- Flora Malesiana precursor for the treatment of Moraceae 3: Ficus subgenus Ficus. Blumea 48: 529-550.

- Flora Malesiana precursor for the treatment of Moraceae 4: Ficus subgenus Synoecia. Blumea 48: 551-571.

- Flora Malesiana precursor for the treatment of Moraceae 5: Ficus subgenus Sycidium. Blumea 48: 573-597.

2004

- A new species of Ficus (Moraceae) of uncertain provenance. Brittonia 56: $54-57$.

- Cecropiaceae. In: Smith N, Mori SA, Henderson A, Stevenson DW, Heald SV (eds), Flowering plants of the Neotropics: 92-94. Princeton \& Oxford.

- Moraceae. In: Smith N, Mori SA, Henderson A, Stevenson DW, Heald SV (eds), Flowering plants of the Neotropics: 253-256. Princeton \& Oxford.

- Ulmaceae. In: Smith N, Mori SA, Henderson A, Stevenson DW, Heald SV (eds), Flowering plants of the Neotropics: 382-383. Princeton \& Oxford.

- Urticaceae. In: Smith N, Mori SA, Henderson A, Stevenson DW, Heald SV (eds), Flowering plants of the Neotropics: $384-385$. Princeton \& Oxford.

- Flora Malesiana precursor for the treatment of Moraceae. Errata. Blumea 49: 154

- Flora Malesiana precursor for the treatment of Moraceae 6: Ficus subgenus Sycomorus. Blumea 49: 155-200.

- Two new species of Pourouma (Cecropiaceae) from South America. Brittonia 56: 255-259.

- Flora Malesiana: additions to and corrections of the Flora Malesiana precursory papers on Ficus subg. Pharmacosycea (2), subg. Synoecia (4), subg . Sycidium (5), and subg. Sycomorus (6): Blumea 49: 461-462.

- Flora Malesiana precursor for the treatment of Moraceae 7: Ficus subgenus Urostigma. Blumea 49: 463-480.

- (with Villavicencio X) Taxonomic studies on Ficus (Moraceae) in the West Indies, extra-Amazonian Brazil, and Bolivia. Ilicifolia 5: 1-132.

2005

- (with Corner EJH) Moraceae (Ficus). Flora Malesiana, Series I - Seed Plants 17, 2. $730 \mathrm{pp}$. Leiden.

- (with Franco Rosselli P and with a chapter by Davidson DW) Cecropia. Flora Neotropica, Monograph 94. $230 \mathrm{pp}$.

- Moraceae diversity in global perspective. In: Friis I, Balslev H (eds), Plant diversity and complexity patterns. Local, regional and global dimensions. Biologiske Skrifter 55: 423-440.

- Cecropiaceae. In: Staples G, Herbst DR (eds), A tropical garden flora: 230-231. Honolulu.

- Moraceae. In: Staples G, Herbst DR (eds), A tropical garden flora: 402-413. Honolulu.

- A new species of Artocarpus (Moraceae) from Thailand. Blumea 50: 531-533.

- Flora Malesiana precursor for the treatment of Moraceae 8: other genera than Ficus. Blumea 50: 535-550.

2006

- The subdivision of Ficus subgenus Pharmacosycea section Pharmacosycea (Moraceae). Blumea 51: 147-151.

- Cecropiaceae. In: Akoègninou A, Van der Burg WJ, Van der Maesen LJG (eds), Flore analytique du Benín: 458-459. Cotonou / Wageningen

- Moraceae. In: Akoègninou A, Van der Burg WJ, Van der Maesen LJG (eds), Flore analytique du Benín: 806-817. Cotonou / Wageningen.

- (with Corner EJH, Jarrett FM) Moraceae (genera other than Ficus). Flora Malesiana, Series I - Seed plants 17, 1. 154 pp. Leiden.
2007

- Precursory taxonomic studies on Ficus (Moraceae) for the Flora of Thailand. Thai Forest Bulletin (Botany) 35: 4-28.

- Leaf dimorphy in Ficus binnendijkii and Ficus maclellandii (Moraceae) and the identity of ornamental trees known under the name ' $F$. longifolia'. Thai Forest Bulletin (Botany) 35: 29-30.

- (with Gardner S) A new species of Ficus subg. Ficus (Moraceae) from Thailand and two new records of Ficus species. Thai Forest Bulletin (Botany) 35: 31-33.

- Two New Guinean Ficus species (Moraceae): one new and the other with an emended description. Blumea 52: 291-294.

- Proposal for treating four species complexes in Ficus subgenus Urostigma section Americanae (Moraceae). Blumea 52: 295-312.

- (with Chantarasuwan B)A study on the taxonomy of some stoloniflorous species of Ficus subsection Sycocarpus (Moraceae) in Thailand and Malesia. Blumea 52: 313-326.

- New species of Ficus (Moraceae) from South America. Blumea 52: 569 594.

- Ficus alongensis (Moraceae) recovered and redefined. Blumea 52: 595 600

2008

- Ficus glandulifera and allied species (Moraceae), including a new one from Borneo and Celebes. Blumea 53: 319-323.

- Ficus capillipes (Moraceae), new for Malesia (Sumatra). Blumea 53: 325_ 327.

- Cecropiaceae. In: Hokche O, Berry PE, Huber O (eds), Nuevo catálogo de la flora vascular de Venezuela: $319-321$. Caracas.

- (with Simonis JE) Moraceae. In: Hokche O, Berry PE, Huber O (eds), Nuevo catálogo de la flora vascular de Venezuela: 505-511. Caracas.

2009

- Moraceae (Ficus). In: Harling G, Persson C (eds), Flora of Ecuador 85 1-146. Göteborg.

2010

- Redefinition of Ficus schwarzii Koord. and two new species of Ficus (Moraceae). Blumea 55: 115-117.

- (with Homeier J) Three new species of South American Moraceae. Blumea 55: $196-200$

2011

- Ficus laurifolia (Moraceae) finally in position. Blumea 56: 159-160.

- Corrective notes on the Malesian members of the genus Ficus (Moraceae). Blumea 56: 161-164.

- Ficus trivia (Moraceae) redefined. Edinburgh Journal of Botany 68: 269 272.

- (with Pattharahirantricin N) Cecropiaceae. Flora of Thailand 10: 469-474. Bangkok.

- (with Pattharahirantricin N, Chantarasuwan B) Moraceae. Flora of Thailand 10: 475-675. Bangkok.

- (with Culmsee H) Ficus schwarzii redefined and two new species of Ficus (Moraceae) from Sulawesi (Indonesia) described. Blumea 56: 265-269.

2012

- Seven new Malesian species of Ficus (Moraceae). Blumea 57: 147-157.

- Cecropiaceae. In: Flora Mesoamericana 2, 2: 1-29. (in press) Internet version, http://www.tropicos.org/docs/meso/cecropiaceae.pdf (seen 8 Dec. 2012).

- Moraceae. In: Flora Mesoamericana 2, 2: 1-91. (in press) Internet version, http://www.tropicos.org/docs/meso/moraceae.pdf (seen 8 Dec. 2012). 